\title{
IDENTIFIKASI KEMAMPUAN BERPIKIR KRITIS MATEMATIS MAHASISWA BERKEMAMPUAN PEMECAHAN MASALAH LEVEL RENDAH DALAM PEMBELAJARAN KALKULUS INTEGRAL BERBASIS PROBLEM BASED LEARNING
}

\author{
Farida Nursyahidah ${ }^{1}$, Irkham Ulil Albab ${ }^{2}$ \\ 1,2 Universitas PGRI Semarang \\ faridanursyahidah@upgris.ac.id
}

\begin{abstract}
Abstrak
Penelitian ini bertujuan untuk mendeskripsikan profil kemampuan berpikir kritis mahasiswa berkemampuan pemecahan masalah level rendah dalam menyelesaikan soal integral Riemann yang disusun berdasarkan indikator kemampuan berpikir kritis matematis. Penelitian ini merupakan penelitian deskriptif kualitatif dengan subjek penelitian adalah mahasiswa kelas IIE tahun pelajaran 2016/2017 Program Studi Pendidikan Matematika FPMIPATI UPGRIS yang sedang mengikuti mata kuliah Kalkulus Integral. Teknik pengumpulan data yang digunakan adalah teknik tes dan wawancara. Berdasarkan hasil penelitian diketahui bahwa profil berpikir kritis mahasiswa berkemampuan pemecahan masalah level rendah meliputi mampu merumuskan masalah dengan benar tetapi kurang lengkap, belum mampu menentukan fakta yang ada pada permasalahan dengan lengkap dan benar, belum mampu menggunakan bukti yang benar, belum mampu menarik kesimpulan sesuai fakta, belum mampu bertindak dengan memberikan penjelasan lanjut, serta belum mampu memadukan kecenderungan dan kemampuan dalam membuat keputusan.
\end{abstract}

Kata kunci: kemampuan berpikir kritis matematis, pemecahan masalah matematis, problem based learning, kalkulus integral

\begin{abstract}
The aim of this research is to describe crithical thinking ability of the students with low problem solving ability in solving problem in Riemann Integral based on the criteria of critical thinking in problem based learning. This is qualitative research with the subject is the students in the class IIE of year 2016/2017 mathematics education departement of FPMIPATI UPGRIS who join the the Calculus Integral course. The data collection used is test and interview. Based on the result of this research can be known that profile of critical thinking ability with the low level of problem solving ability was can do basic clarification, can not do bases for a decision, can not do inference, can not do advance clarification, and can not do supposition and integration.
\end{abstract}

Keywords: mathematical critical thinking ability, mathematical problem solving, problem based learning, integral calculus

\section{PENDAHULUAN}

Salah satu kompetensi penting yang harus dimiliki setiap individu pada abad 21 adalah kemampuan berpikir kritis (Kalelioglu \& Gulbahar, 2013; Kriel, 2013; Aizikovitsh-Udi \& Cheng, 2015). Menurut Facione (2011), kemampuan paling dasar dalam berpikir kritis adalah kemampuan interpretasi, analisis, evaluasi, menyimpulkan, menjelaskan, dan pengendalian diri. Sedangkan menurut Mansoor and Pezeshki (2012), berpikir kritis memuat penalaran 
mendalam dan kesadaran tentang apa yang kita terima daripada penerimaan langsung dari perbedaan suatu ide. Artinya, ide dan saran dari seseorang tentang suatu fenomena tidak dapat langusng diterima sepenuhnya jika ide tersebut tidak berjalan secara sistematis dan proses pencarian kebenaran yang logis. Sejalan dengan hal tersebut Ennis (2011) mengemukakan indikator kemampuan berpikir kritis matematis diantaranya: merumuskan pertanyaan, menanyakan dan menjawab pertanyaan; melakukan observasi dan menilai laporan observasi; membuat induksi dan menilai induksi; mendefinisikan dan menilai definisi; dan memadukan.

Beberapa penelitian yang telah dilakukan menunjukkan bahwa pengembangan kemampuan berpikir kritis dapat meningkatkan prestasi matematika (Jacob, 2012; Chukwuyenum, 2013). Selain itu, penguasaan kemampuan berpikir kritis akan berimplikasi pada kemampuan menyelesaikan masalah secara efektif (Peter, 2012). Selanjutnya, Jacob (2012) juga menambahkan bahwa kemampuan berpikir kritis dapat merangsang siswa untuk berpikir mandiri dan dapat menyelesaikan masalah di sekolah atau dalam kehidupan seharihari. Oleh karena itu, kemampuan berpikir kritis perlu dikuasai oleh mahasiswa.

Mahasiswa merupakan agent of change yang perlu dibekali berbagai kemampuan dan keterampilan baik itu berupa hard skill maupun soft skill untuk dapat bertahan hidup dan mampu bersaing dalam dunia yang semakin berkembang. Salah satu kemampuan yang perlu dikuasai oleh mahasiswa program studi pendidikan matematika adalah berupa kemampuan berpikir kritis pada pemecahan masalah. Untuk dapat menguasai kemampuan tersebut, salah satunya adalah dengan penerapan pembelajaran pada mata kuliah kalkulus integral berbasis problem based learning. Dalam pembelajaran mata kuliah kalkulus, mahasiswa dilatih untuk mengemukakan argumen baik tertulis maupun lisan dalam menyelesaikan masalah sehingga hal ini dapat menstimulus kemampuan berpikir kritisnya. Seperti yang dikemukakan oleh Aizikovitsh-Udi (2012) bahwa kemampuan berargumen dapat diaplikasikan dalam berbagai kegiatan diskusi matematika dan khususnya dapat digunakan di kelas matematika saat mahasiswa menyelesaikan masalah non rutin yang menantang.

Menurut wawancara yang dilakukan terhadap dosen pengampu maupun mahasiswa yang mengikuti mata kuliah kalkulus integral, banyak diantara mahasiswa masih mengalami kesulitan dalam pemecahan masalah pada mata kuliah tersebut. Hal itu tentunya akan berpengaruh terhadap kemampuan berpikir kritis mahasiswa baik dalam menyelesaikan soal kalkulus integral maupun dalam menyelesaikan masalah dalam kehidupan sehai-hari. Menurut Osarenren and Asiedu (2007), alasan rendahnya kemampuan matematika siswa disebabkan oleh ketidakmampuannya dalam berpikir kritis and menganalisis konsep matematika secara sistematis. Oleh karena itu, berpikir kritis merupakan konsep yang sangat 
penting yang diperlukan untuk meningkatkan kemampuan dalam berbagai matapelajaran khususnya matematika.

Di sisi lain, mahasiswa sebagai civitas akademika diharapkan mampu menguasai kemampuan berpikir kritis agar dapat memberikan kontribusi bagi masyarakat pada bidang ilmunya masing-masing setelah mereka menyelesaikan pendidikannya. Demikian juga bagi perguruan tinggi juga diharapkan mampu menghasilkan alumni yang dapat mengimplementasikan kemampuan kognitifnya untuk memecahkan berbagai masalah yang tidak hanya terbatas pada salah satu bidang saja. Dengan demikian, dalam pembelajaran matematika khususnya yang terkait dengan penyelesaian masalah matematika yaitu dalam mata kuliah kalkulus integral berbasis problem based learning perlu diidentifikasi tahap berpikir kritis mahasiswa untuk dapat diperoleh deskripsi profil tahap berpikir kritis dalam pemecahan masalah matematika khususnya pada mahasiswa yang masih mempunyai kemampuan pemecahan masalah matematis level rendah dan dapat ditemukan alternatif solusi untuk dapat membantu kesulitan belajar mereka sehingga kemampuan pemecahan masalah mahasiswa dapat meningkat.

Berdasarkan uraian di atas, di dalam artikel ini akan dideskripsikan profil kemampuan berpikir kritis mahasiswa berkemampuan pemecahan masalah matematis level rendah dalam menyelesaikan soal kalkulus integral dalam pembelajaran berbasis problem based learning.

\section{METODE}

Penelitian ini merupakan penelitian deskriptif kualitatif. Menurut Bogdan dan Taylor, metodologi kualitatif sebagai prosedur penelitian menghasilkan data deskriptif berupa katakata tertulis dan lisan dari orang-orang dan perilaku yang dapat diamati (Moleong, 2010). Dalam penelitian ini, data yang dideskripsikan adalah berupa profil kemampuan berpikir kritis mahasiswa berkemampuan pemecahan masalah level rendah.

Teknik pengumpulan data dalam penelitian ini dilakukan dengan metode tes tertulis dan wawancara. Dalam penelitian ini digunakan tes kemampuan pemecahan masalah matematis dan tes kemampuan berpikir kritis matematis. Tes kemampuan pemecahan masalah matematis diberikan kepada mahasiswa yang digunakan untuk mengetahui tingkat kemampuan pemecahan masalah matematis mahasiswa untuk menentukan subjek penelitian. Tes kemampuan berpikir kritis matematis diberikan kepada subjek penelitian dan digunakan untuk mendeskripsikan kemampuan berpikir kritis mahasiswa dalam memecahkan masalah matematika. Metode wawancara digunakan untuk mendapatkan informasi lebih jelas tentang 
kemampuan berpikir kritis mahasiswa dalam memecahkan masalah matematika. Wawancara direkam dengan menggunakan alat perekam suara sebagai bahan dokumentasi peneliti untuk keperluan analisis data. Dalam penelitian ini menggunakan triangulasi data, yaitu melakukan pengecekan dengan tes tertulis dan wawancara semi terstruktur dalam waktu dan situasi yang berbeda.

Teknik analisis data yang digunakan di dalam penelitian ini ada dua bagian, yaitu analisis data hasil tes tertulis dan analisis data hasil wawancara. Data hasil tes tertulis dianalisis dengan mendeskripsikan komponen-komponen berpikir kritis mahasiswa berkemampuan pemecahan masalah level rendah. Selanjutnya analisis data hasil wawancara dilakukan dengan cara mereduksi data, memaparkan data, dan menarik simpulan.

\section{HASIL DAN PEMBAHASAN}

\section{Hasil Penelitian}

Dalam penelitian ini diperoleh hasil analisis kemampuan berpikir kritis matematis subjek berkemampuan pemecahan masalah rendah (PMR) menurut lima indikator sebagai berikut.

\section{Indikator Merumuskan Pertanyaan}

Pekerjaan subjek PMR terkait indikator merumuskan pertanyaan pada soal tes 1 dapat dilihat pada gambar 1 .

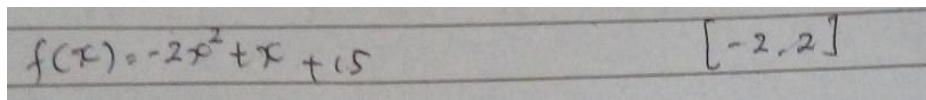

Gambar 1. Mengidentifikasi dan merumuskan masalah PMR pada soal tes 1

Pada gambar tersebut dapat diketahui bahwa subjek PMR mampu mengidentifikasi dan merumuskan permasalahan pada soal 1 meskipun masih kurang lengkap, namun tidak menuliskan pertanyaan secara eksplisit. Terkait dengan hal tersebut, kutipan wawancara peneliti dengan subjek PMR terkait indikator merumuskan pertanyaan disajikan sebagai berikut.

Skrip 1 PMR. Kutipan wawancara peneliti dengan subjek PMR terkait indikator merumuskan pertanyaan pada soal tes 1

$\begin{array}{ll}P & : \text { Apa yang ditanyakan pada soal nomor } 1 ? \\ P M R & \text { : Jumlah Riemann dari fungsi } f(x)=-2 x^{2}+x+15 \text { pada selang [-2,2] } \\ & \text { dibagi menjadi } 8 \text { partisi sama panjang dan titik sampelnya adalah titik } \\ & \text { ujung kanan }\end{array}$


Kutipan wawancara menunjukkan bahwa subjek PMR mampu merumuskan pertanyaan sesuai dengan soal dan terkesan hanya membaca persis dengan soal. PMR kurang mampu mengelaborasi pertanyaan yang ada di dalam soal.

Berdasarkan triangulasi dari hasil tes subjek PMR dan hasil wawancara peneliti dengan subjek PMR, dapat dikatakan bahwa data subjek PMR terkait indikator merumuskan pertanyaan pada soal 1 valid. Jadi, dapat ditarik simpulan bahwa subjek PMR mampu merumuskan pertanyaan pada soal nomor 1 tetapi masih kurang lengkap.

Selanjutnya, disajikan hasil jawaban PMR pada soal tes 2 pada gambar 2 sebagai berikut.

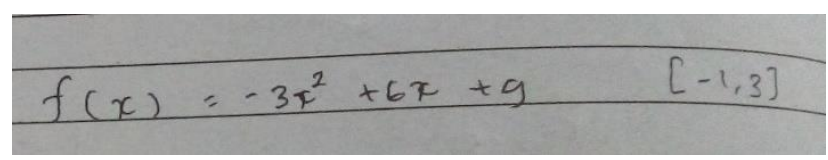

Gambar 2. Pekerjaan PMR terkait indikator mengidentifikasi dan merumuskan masalah pada soal tes 2

Pekerjaan subjek PMR terkait indikator merumuskan pertanyaan pada soal tes 2 dapat dilihat pada gambar 2. Pada gambar tersebut menunjukkan bahwa subjek PMR mampu mengidentifikasi dan merumuskan permasalahan pada soal tes 2 tetapi masih kurang lengkap dan tidak menuliskan pertanyaan secara eksplisit. Terkait dengan hal tersebut, kutipan wawancara peneliti dengan subjek PMR terkait indikator merumuskan pertanyaan disajikan sebagai berikut.

Skrip 2 PMR. Kutipan wawancara peneliti dengan subjek PMR terkait indikator merumuskan pertanyaan pada soal tes 2

\begin{tabular}{|ll}
$P$ & : Apa yang ditanyakan pada soal nomor $1 ?$ \\
PMR & : Jumlah Riemann dari fungsi $f(x)=-3 x^{2}+6 x+9$ pada selang $[-1,3]$ \\
& dibagi menjadi 8 partisi sama panjang dan titik sampelnya adalah titik \\
& tengah
\end{tabular}

Kutipan wawancara menunjukkan bahwa subjek PMR mampu merumuskan pertanyaan sesuai dengan soal tetapi terkesan hanya membaca soal. PMR juga belum mampu mengelaborasi pertanyaan yang ada di dalam soal dan menguraikan secara lebih rinci.

Berdasarkan triangulasi dari hasil tes subjek PMR dan hasil wawancara peneliti dengan subejk PMR, dapat dikatakan bahwa data subjek PMR terkait indikator merumuskan pertanyaan pada soal 2 valid. Jadi, dapat ditarik simpulan bahwa subjek PMR mampu merumuskan pertanyaan pada soal nomor 2 meskipun masih kurang lengkap.

Dari hasil analisis data yang dilakukan terhadap indikator merumuskan pertanyaan pada soal tes 1 dan 2 dapat disimpulkan bahwa subjek PMR mampu merumuskan masalah dengan benar namun kurang lengkap. 


\section{Indikator Melakukan Observasi dan Menilai Laporan Hasil Observasi}

Pekerjaan subjek PMR terkait indikator melakukan observasi dan menilai laporan observasi pada soal tes 1 dapat dilihat pada gambar 3 .

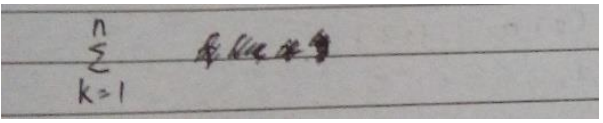

Gambar 3. Hasil PMR melakukan observasi dan menilai laporan hasil observasi pada soal tes 1

Gambar 3 menunjukkan bahwa subjek PMR belum mampu menuliskan rumus jumlah Riemann pada soal 1 dengan benar dan tepat. Hal ini menunjukkan bahwa subjek PMR belum mampu melakukan observasi dan menuliskan bukti-bukti yang benar. Terkait hal tersebut, kutipan wawancara peneliti dengan subjek PMR disajikan sebagai berikut.

Skrip 3 PMR. Kutipan wawancara peneliti dengan subjek PMR terkait indikator melakukan observasi dan menilai laporan hasil observasi pada soal tes 1

\begin{tabular}{|ll|}
\hline$P$ & $:$ Bagaimana menyelesaikan masalah nomor $1 ?$ \\
$P M R$ & $:$ menggunakan rumus Bu \\
$P$ & $:$ Rumus apa yang digunakan? \\
$P M R$ & $:$ Rumus Jumlah Riemann, tapi saya lupa Bu, he.. \\
$P$ & $:$ Kok bisa lupa? \\
$P M R$ & $:$ Karena pada saat di kelas masih kurang paham \\
\hline
\end{tabular}

Kutipan wawancara tersebut menunjukkan bahwa subjek PMR belum mampu menyebutkan sumber informasi jawaban dan bukti yang benar dari pada tes 1 yaitu rumus jumlah Riemann yang benar dari guru dan dari buku. Subjek PMR tidak yakin dengan jawaban yang diberikan.

Berdasarkan triangulasi dari hasil tes subjek PMR dan hasil wawancara peneliti dengan subjek PMR, dapat dikatakan bahwa data subjek PMR terkait indikator melakukan observasi dan menilai laporan hasil observasi pada soal tes 1 valid. Jadi, dapat ditarik simpulan bahwa subjek PMR belum mampu mnggunakan bukti-bukti yang benar pada soal tes 1 dengan tepat dan lengkap.

Selanjutnya, pekerjaan subjek PMR terkait indikator melakukan observasi dan menilai laporan observasi pada soal tes 2 tidak dapat terlihat pada gambar, karena subjek PMR tidak mampu untuk menuliskan rumus yang akan digunakan untuk menyelesaikan masalah pada soal tes 2 . Terkait hal tersebut, kutipan wawancara peneliti dengan subjek PMR disajikan sebagai berikut.

Skrip 4 PMR. Kutipan wawancara peneliti dengan subjek PMR terkait indikator melakukan observasi dan menilai laporan hasil observasi pada soal tes 2 


\begin{tabular}{|ll|}
\hline$P$ & $:$ Bagaimana menyelesaikan masalah pada tes 2? \\
$P M R$ & $:$ menggunakan rumus Bu \\
$P$ & $:$ Rumus apa yang digunakan? \\
$P M R$ & $:$ Rumus Riemann... tapi saya lupa \\
\hline
\end{tabular}

Kutipan wawancara tersebut menunjukkan bahwa subjek PMR belum mampu menyebutkan sumber informasi jawaban dan bukti yang benar dari tes 2 yaitu rumus jumlah Riemann yang benar dari guru dan dari buku. Subjek PMR sama sekali tidak yakin dan ragu-ragu dengan jawaban yang diberikan.

Berdasarkan triangulasi dari hasil tes subjek PMR dan hasil wawancara peneliti dengan subjek PMR, dapat dikatakan bahwa data subjek PMR terkait indikator melakukan observasi dan menilai laporan hasil observasi pada soal test 2 valid. Jadi, dapat ditarik simpulan bahwa subjek PMR belum mampu menggunakan bukti-bukti yang benar pada soal tes 2 .

Dari hasil analisis data yang dilakukan terhadap indikator melakukan observasi dan menilai laporan hasil observasi pada soal tes 1 dan 2 dapat disimpulkan bahwa subjek PMR belum mampu menggunakan bukti-bukti yang benar.

\section{Indikator Membuat Induksi dan Menilai Induksi}

Pekerjaan subjek PMR terkait indikator membuat induksi dan menilai induksi pada soal 1 dapat dilihat pada gambar 5 sebagai berikut.

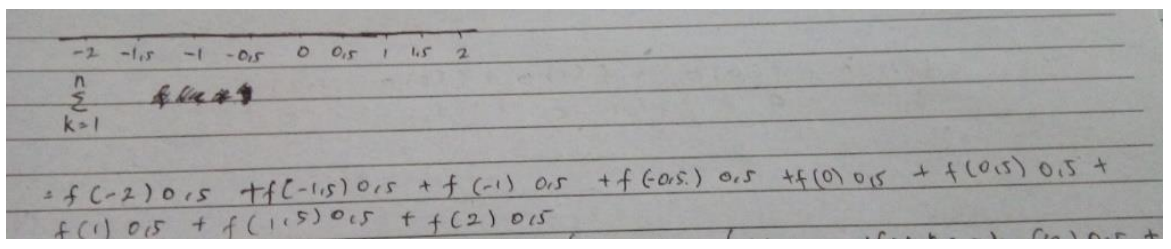

Gambar 5. Hasil PMR membuat induksi dan menilai induksi

Pada gambar 5 tersebut menunjukkan bahwa subjek PMR belum mampu menuliskan kesimpulan dari permasalahan pada soal tes 1 dengan benar. Subjek tidak dapat menjawab pertanyaan dan menuliskan kesimpulan dari permasalahan pada soal tes 1 . Terkait dengan hal tersebut, kutipan wawancara peneliti dengan subjek PMR terkait indikator melakukan observasi dan menilai laporan hasil observasi disajikan sebagai berikut.

Skrip 5 PMR. Kutipan wawancara peneliti dengan subjek PMR terkait indikator membuat induksi dan menilai induksi pada soal tes 1 


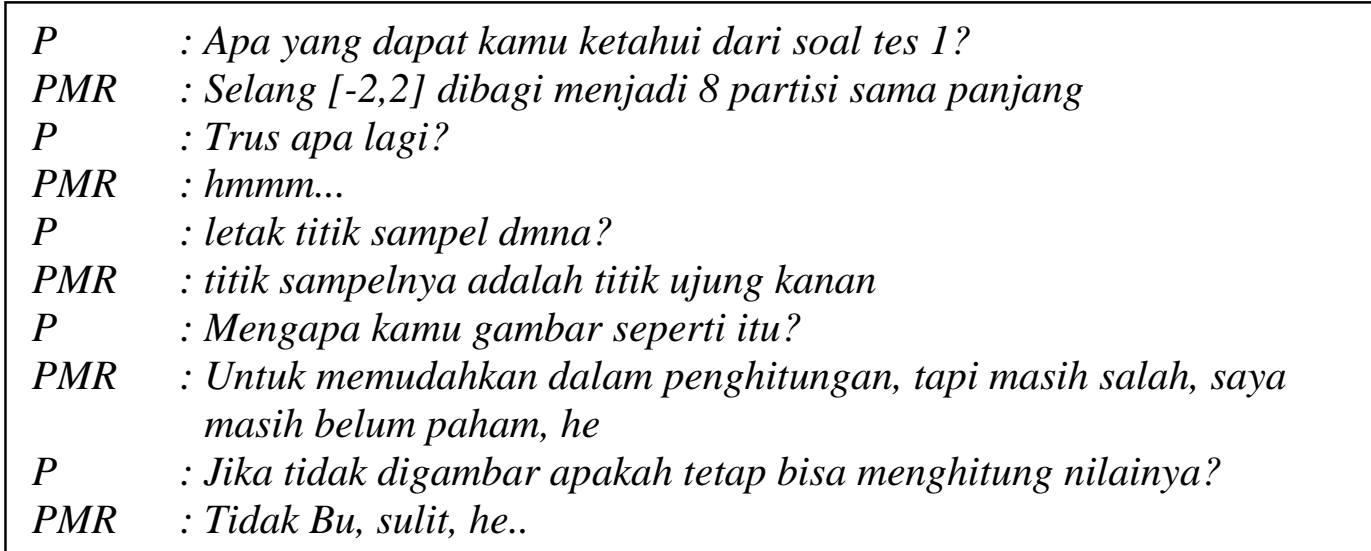

Kutipan wawancara menunjukkan bahwa subjek PMR mampu menyebutkan kesimpulan dari permasalahan pada soal tes 1. Selain itu, PMR juga belum mampu menilai induksi permasalahan dengan menjelaskan secara detil tiap interval pada selang yang diketahui.

Berdasarkan triangulasi dari tes subjek PMR dan hasil wawancara peneliti dengan subjek PMR, dapat dikatakan bahwa data subjek PMR terkait indikator membuat induksi dan dan menilai induksi pada soal tes 1 valid. Jadi, dapat ditarik simpulan bahwa subjek PMR belum mampu menarik kesimpulan sesuai fakta pada soal tes 1 .

Selanjutnya, disajikan hasil jawaban PMR pada soal tes 2 sebagai berikut.

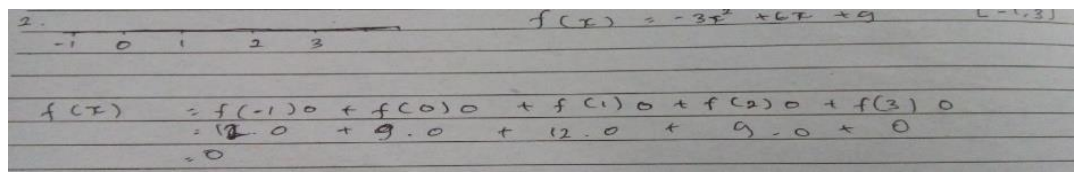

Gambar 6. Hasil PMR membuat induksi dan menilai induksi pada soal tes 2

Pekerjaan subjek PMR terkait indikator membuat induksi dan menilai induksi pada soal tes 2 dapat dilihat pada gambar 6. Berdasarkan gambar tersebut dapat diketahui bahwa subjek PMR belum mampu membuat induksi dan menilai induksi pada soal tes 2 dengan lengkap dan benar. Terkait dengan hal tersebut, kutipan wawancara peneliti dengan subjek PMR terkait indikator melakukan observasi dan menilai laporan hasil observasi disajikan sebagai berikut.

Skrip 6 PMR. Kutipan wawancara peneliti dengan subjek PMR terkait indikator membuat induksi dan menilai induksi pada soal tes 2

\begin{tabular}{|ll|}
\hline$P$ & $:$ Apa yang dapat kamu ketahui dari soal tes 2 ? \\
$P M R$ & $:$ selang [-1,3] dibagi menjadi 8 partisi sama panjang \\
$P$ & $:$ Apa lagi? \\
$P M R$ & $:$ Titik sampelnya adalah 0,25 kurangnya dari titik ujung kanan, \\
$P$ & $:$ Mengapa kamu gambar seperti itu? \\
$P M R$ & $:$ Untuk memudahkan dalam penghitungan, tapi belum paham \\
$P$ & $:$ Jika tidak digambar apakah tetap bisa menghitung nilainya? \\
$P M R$ & $:$ Tidak bisa Bu, masih belum paham, bingung, he.. \\
\hline
\end{tabular}


Kutipan wawancara menunjukkan bahwa subjek PMR belum mampu membuat induksi dan menilai induksi pada soal tes 2. Selain itu, PMR juga belum mampu menjelaskan langkah demi langkah yang dilakukan untuk menentukan penyelesaian dari masalah pada tes 2 .

Berdasarkan triangulasi dari tes subjek PMR dan hasil wawancara peneliti dengan subjek PMR, dpat dikatakan bahwa data subjek PMR terkait indikator membuat induksi dan dan menilai induksi pada soal tes 2 valid. Jadi, dapat ditarik simpulan bahwa subjek PMR belum mampu menarik kesimpulan sesuai fakta pada soal tes 2 .

Dari hasil analisis data yang dilakukan terhadap indikator membuat induksi dan dan menilai induksi pada soal nomor tes 1 dan 2 dapat disimpulkan bahwa subjek PMR belum mampu menyimpulkan dan memberikan keputusan dari masalah yang diberikan.

\section{Indikator Mendefinisikan dan Menilai Definisi}

Pekerjaan subjek PMR terkait indikator mendefinisikan dan menilai definisi pada soal tes 1 dapat dilihat pada gambar 7 berikut.

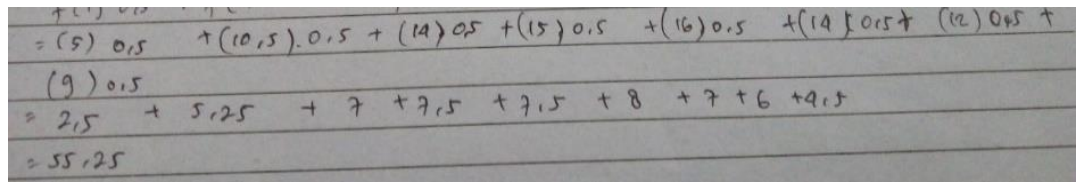

Gambar 7. Hasil PMR mendefinisikan dan menilai definisi pada soal tes 1

Pada gambar tersebut dapat diketahui bahwa subjek PMR belum mampu menuliskan definisi/sumber lebih lanjut untuk menyelesaikan masalah berupa ketentuan yang disepakati dalam penghitungan jumlah Riemann pada soal tes 1. Terkait dengan hal tersebut, kutipan wawancara peneliti dengan subjek PMR terkait indikator membuat induksi dan menilai induksi disajikan sebagai berikut.

Skrip 7 PMR. Kutipan wawancara peneliti dengan subjek PMR terkait indikator mendefinisikan dan menilai definisi pada soal tes 1

$P \quad$ : Kira-kira bisa membuat gambaran penyelesaian masalah pada tes $1 ?$

PMR : Masih bigung Bu, bingung menentukan selang dan titik sampel, he..

Kutipan wawancara menunjukkan bahwa subjek PMR tidak mampu mendefinisikan pada soal tes 1. PMR masih bingung menentukan pembagian selang dan titik sampel.

Berdasarkan triangulasi dari tes subjek PMR dan hasil wawancara peneliti dengan subjek PMR, dapat dikatakan bahwa data subjek PMR terkait indikator mendefinisikan dan menilai definisi pada soal tes 1 valid. Jadi, dapat ditarik simpulan bahwa subjek PMR tidak mampu menjelaskan rumus/definisi pendukung dalam menyelesaikan keputusan pada soal tes 1 . 
Selanjutnya, disajikan hasil jawaban PMR pada soal tes 2 sebagai berikut.

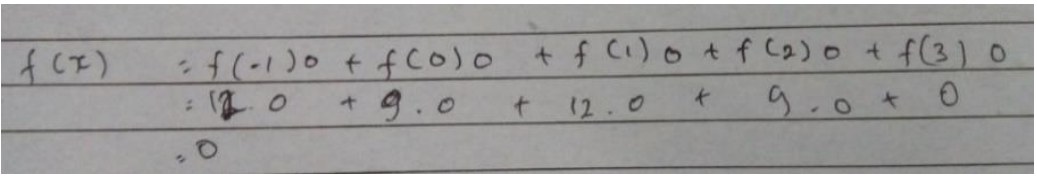

Gambar 8. Hasil PMR mendefinisikan dan menilai definisi pada soal tes 2

Pada gambar tersebut dapat diketahui bahwa subjek PMR belum mampu menuliskan definisi/sumber lebih lanjut untuk menyelesaikan masalah berupa ketentuan yang disepakati dalam penghitungan jumlah Riemann pada soal tes 2. Menentukan nilai $f(x)$ juga masih belum bisa. Selanjutnya, menentukan nilai $\Delta x$ juga belum bisa. Sehingga proses kalkulasinya masih salah. Terkait dengan hal tersebut, kutipan wawancara peneliti dengan subjek PMR terkait indikator membuat induksi dan menilai induksi disajikan sebagai berikut.

Skrip 8 PMR. Kutipan wawancara peneliti dengan subjek PMR terkait indikator mendefinisikan dan menilai definisi pada soal 2

$$
\begin{aligned}
& P \quad: \text { : Ini kenapa hasilnya kok nol semua? } \\
& \text { PMR : Iya Bu, krena } \Delta x \text { nya } 0 \text {. Hmm, saya masih bingung bu, makanya }
\end{aligned}
$$

Kutipan wawancara menunjukkan bahwa subjek PMR tidak mampu mendefinisikan pada soal tes 2. Selain itu, PMR juga tidak mampu menilai definisi dari permasalahan pada tes 2. Sehingga menghasilkan proses yang salah dan hasil juga salah. Dan tidak melanjutkan lagi ke proses perhitungan selajutnya, karena tidak yakin dan bingung.

Berdasarkan triangulasi dari tes subjek PMR dan hasil wawancara peneliti dengan subjek PMR, dapat dikatakan bahwa data subjek PMR terkait indikator mendefinisikan dan menilai definisi pada soal tes 2 valid. Jadi, dapat ditarik simpulan bahwa subjek PMR tidak mampu menjelaskan rumus/definisi pendukung dalam menyelesaikan keputusan pada soal tes 2 .

Dari hasil analisis data yang dilakukan terhadap indikator mendefinisikan dan menilai definisi pada soal tes 1 dan 2 dapat disimpulkan bahwa subjek PMR tidak mampu menjelaskan rumus/definisi pendukung dalam menyelesaikan keputusan memadukan kecenderungan dan kemampuan dalam membuat keputusan.

\section{Indikator Memadukan}

Pekerjaan subjek PMR terkait indikator mendefinisikan dan menilai definisi pada soal tes 1 dapat dilihat pada gambar 9. 


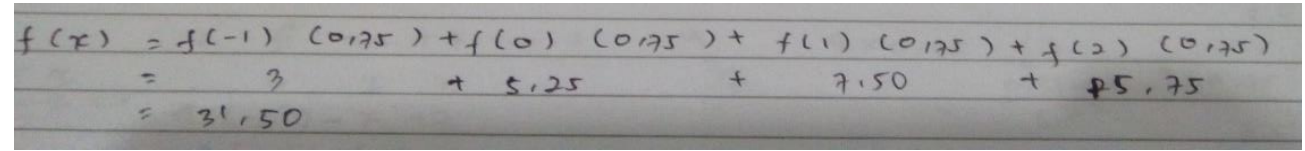

Gambar 9. Hasil PMR memadukan pada soal tes 1

Berdasarkan gambar tersebut dapat diketahui bahwa subjek PMR belum mampu memadukan hasil yang diperoleh dari indikator sebelumnya yaitu indikator merumuskan pertanyaan dan indikator melakukan observasi dan menilai laporan hasil observasi pada soal tes 1. Hal ini dikarenakan pada indikator menanyakan dan menjawab pertanyaan, subjek belum mampu menuliskan dan menyebutkan titik sampel berdasarkann ketentuan yang ada di dalam soal, tetapi masih bingung dalam menentukan titik sampel dan membagi selang dalam interval yang diketahui. Terkait dengan hal tersebut, kutipan wawancara peneliti dengan subjek PMR terkait indikator memadukan disajikan sebagai berikut.

Skrip 9 PMR. Kutipan wawancara peneliti dengan subjek PMR terkait indikator memadukan pada soal 1

\begin{tabular}{|ll|}
\hline$P$ & $:$ Mengapa kamu banyak melakukan coretan seperti ini? \\
$P M R$ & $:$ Karena belum paham Bu, masih ragu dan salah \\
$P$ & $:$ Kurang paham bagaimana? Bagian mana yang belum paham? \\
$P M R$ & $:$ Ini Bu, cara menentukan panjang selang dan titik sampelnya saya \\
& masih bingung, makanya tadi banyak saya coret, dan ini saya tidak \\
& yakin
\end{tabular}

Berdasarkan kutipan wawancara tersebut dapat diketahui bahwa subjek PMR belum mampu menyebutkan alasan/penjelasan pada soal 1 dengan lancar. Jadi banyak melakukan kesalahan karena penuh keragu-raguan dalam melangkah. Selain itu, PMR juga belum mampu memberikan alasan yang tepat dan belum mampu memadukan sumber yang didapatkan pada indikator merumuskan pertanyaan, menanyakan dan menjawa pertanyaan, indikator melakukan observasi dan menilai laporan hasil observasi dan indikator mendefinisikan dan menilai definisi.

Berdasarkan triangulasi dari hasil tes subjek PMR dan hasil wawancara peneliti dengan subjek PMR, dapat dikatakan bahwa data subjek PMR terkait indikator memadukan pada soal tes 1 valid. Jadi dapat ditarik simpulan bahwa subjek PMR belum mampu memadukan kesenderungan dan kemampuan dalam membuat keputusan pada soal tes 1 .

Selanjutnya, disajikan hasil jawaban PMR pada soal tes 2 sebagai berikut.

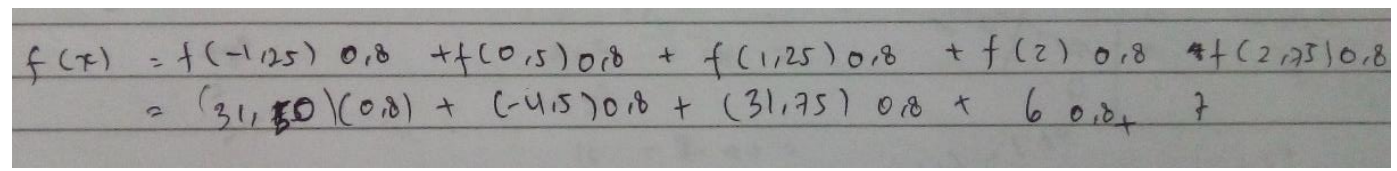

Gambar 10. Hasil PMR memadukan pada soal tes 2 
Berdasarkan gambar tersebut dapat diketahui bahwa subjek PMR belum mampu memadukan hasil yang diperoleh dari indikator sebelumnya yaitu indikator merumuskan pertanyaan dan indikator melakukan observasi dan menilai laporan hasil observasi pada soal tes 2. Hal ini dikarenakan pada indikator menanyakan dan menjawab pertanyaan, subjek belum mampu menuliskan dan menyebutkan titik sampel berdasarkann ketentuan yang ada di dalam soal, yaitu berupa 0,25 kurangnya dari titik ujung kanan. PMR masih kesulitan dalam menentukan selang dan titik sampel, sehingga dalam melakukan perhitngan tidak tuntas. Hal ini dikarenakan masalah yang diberikan ini tidak biasa seperti yang diberikan di kelas dimana biasanya titik sampel merupakan titik tengah atau suatu titik tertentu yang sudah diketahui. Tetapi juga karena PMR masih belum paham dengan masalah Jumlah Riemann. Selanjutnya PMR juga belum mampu memadukan informasi yang ada di dalam soal, kemudian melakukan perhitungan, dan menarik sempulan dengan menjawab pertanyaan yang ada pada soal. Terkait dengan hal tersebut, kutipan wawancara peneliti dengan subjek PMR terkait indikator memadukan disajikan sebagai berikut.

Skrip 10 PMR. Kutipan wawancara peneliti dengan subjek PMR terkait indikator memadukan pada soal tes 2

$$
\begin{array}{ll}
P & : \text { Mengapa kamu tidak menyelesaikan proses perhitungan ini? } \\
P M R & : \text { Iya Bu, karena saya bingung } B u, \text { jadi tidak saya lanjutkan }
\end{array}
$$

Berdasarkan kutipan wawancara tersebut dapat diketahui bahwa subjek PMR belum mampu menyebutkan alasan/penjelasan pada soal tes 2 dengan lancar. Jadi banyak melakukan kesalahan karena penuh keragu-raguan dalam melangkah. Selain itu, PMR juga belum mampu memberikan alasan yang tepat dan belum mampu memadukan sumber yang didapatkan pada indikator merumuskan pertanyaan, menanyakan dan menjawa pertanyaan, indikator melakukan observasi dan menilai laporan hasil observasi dan indikator mendefinisikan dan menilai definisi.

Berdasarkan triangulasi dari hasil tes subjek PMR dan hasil wawancara peneliti dengan subjek PMR, dapat dikatakan bahwa data subjek PMR terkait indikator memadukan pada soal tes 2 valid. Jadi dapat ditarik simpulan bahwa subjek PMR belum mampu memadukan kesenderungan dan kemampuan dalam membuat keputusn pada soal tes 2 .

Dari hasil analisis data yang dilakukan terhadap indikator memadukan pada soal tes 1 dan 2 dapat disimpulkan bahwa subjek PMR belum mampu memadukan kecenderungan dan kemampuan dalam membuat keputusan. 
Setelah dilakukan analisis data kemampuan berpikir kritis dari hasil tes kemampuan berpikir kritis dan data transkrip wawancara pada subjek berkemampuan pemecahan masalah level rendah pada tes 1 dan 2 diperoleh data analisis kemampuan berpikir kritis berdasarkan kemampuan pemecahan masalah matematis subjek PMR yang disajikan pada tabel 1 berikut.

Tabel 1. Analisis Kemampuan Berpikir Kritis Matematis PMR pada Tes 1 dan 2

\begin{tabular}{|c|c|c|c|}
\hline Indikator & Tes 1 & Tes 2 & Simpulan \\
\hline 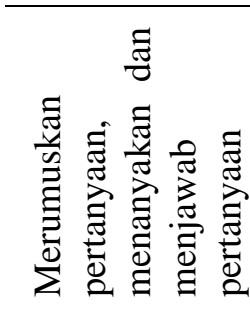 & $\begin{array}{l}\text { Mampu merumuskan } \\
\text { masalah dengan benar } \\
\text { tetapi belum lengkap serta } \\
\text { kurang mampu } \\
\text { menentukan fakta yang } \\
\text { ada pada permasalahan }\end{array}$ & $\begin{array}{l}\text { Mampu merumuskan } \\
\text { masalah dengan benar } \\
\text { tetapi kurang lengkap } \\
\text { serta kurang mampu } \\
\text { menentukan fakta yang } \\
\text { ada pada permasalahan }\end{array}$ & $\begin{array}{l}\text { Mampu merumuskan } \\
\text { masalah dengan benar } \\
\text { tetapi kurang lengkap } \\
\text { serta kurang mampu } \\
\text { menentukan fakta yang } \\
\text { ada pada permasalahan }\end{array}$ \\
\hline 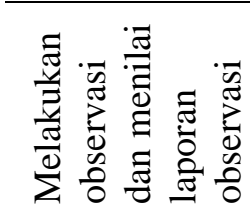 & $\begin{array}{l}\text { Kurang mampu } \\
\text { menggunakan bukti-bukti } \\
\text { yang benar dan tepat }\end{array}$ & $\begin{array}{l}\text { Kurang } \quad \text { mampu } \\
\text { menggunakan bukti- } \\
\text { bukti yang benar dan } \\
\text { tepat }\end{array}$ & $\begin{array}{l}\text { Kurang mampu } \\
\text { menggunakan bukti- } \\
\text { bukti yang benar dan } \\
\text { tepat }\end{array}$ \\
\hline 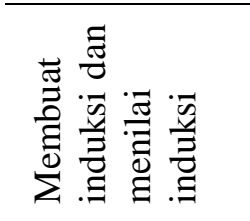 & $\begin{array}{l}\text { Kurang mampu menarik } \\
\text { simpulan sesuai fakta }\end{array}$ & $\begin{array}{l}\text { Kurang mampu menarik } \\
\text { simpulan sesuai fakta }\end{array}$ & $\begin{array}{lr}\text { Kurang } & \text { mampu } \\
\text { menarik } & \text { simpulan } \\
\text { sesuai fakta } & \end{array}$ \\
\hline 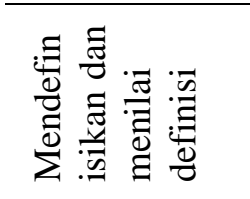 & $\begin{array}{l}\text { Kurang mampu bertindak } \\
\text { dengan memberikan } \\
\text { penjelasan lanjut }\end{array}$ & $\begin{array}{lr}\text { Kurang } & \text { mampu } \\
\text { bertindak } & \text { dengan } \\
\text { memberikan } & \text { penjelasan } \\
\text { lanjut } & \end{array}$ & $\begin{array}{l}\text { Kurang mampu } \\
\text { bertindak dengan } \\
\text { memberikan } \\
\text { penjelasan lanjut }\end{array}$ \\
\hline 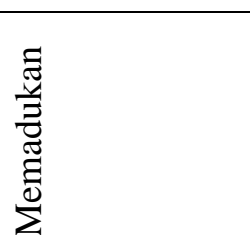 & $\begin{array}{l}\text { Kurang mampu } \\
\text { memadukan } \\
\text { kecenderungan dan } \\
\text { kemampuan dalam } \\
\text { membuat keputusan }\end{array}$ & $\begin{array}{l}\text { Kurang mampu } \\
\text { memadukan } \\
\text { kecenderungan dan } \\
\text { kemampuan dalam } \\
\text { membuat keputusan }\end{array}$ & $\begin{array}{l}\text { Kurang mampu } \\
\text { memadukan } \\
\text { kecenderungan dan } \\
\text { kemampuan dalam } \\
\text { membuat keputusan }\end{array}$ \\
\hline
\end{tabular}

\section{Pembahasan}

Hasil penelitian ini menunjukkan bahwa kemampuan berpikir kritis PMR pada tes 1 dan tes 2 memiliki beberapa persamaan dan perbedaan. Persamaan itu terletak pada indikator merumuskan masalah. Pada indikator ini, PMR pada tes 1 dan 2 sama-sama mampu menuliskan masalah tetapi masih hampir serupa dengan soal. Pada saat interview, PMR juga hanya mampu sebatas membaca soal dan persis kalimat dengan yang ada pada soal, jadi PMR kurang mampu mengelaborasi masalah dan apa yang ditanyakan di dalam soal. Selanjutnya, pada indikator menanyakan dan menjawab pertanyaan, baik pada tes 1 maupun tes 2, PMR 
mampu menanyakan masalah dalam soal serta menjawab masalah yang ada dalam soal tersebut.

Pada indikator melakukan observasi dan menilai laporan hasil observasi, pada kedua tes yaitu tes 1 dan tes 2, PMR kurang mampu menggunakan bukti-bukti yang benar. PMR mampu menuliskan rumus apa yang akan digunakan untuk menyelesaikan masalah yang ada pada soal tetapi tidak lengkap karena PMR sebatas menghafalkan rumus tersebut tanpa adanya pemahaman akan materi tersebut dengan baik. Untuk soal pada tes 1 dan 2, PMR mampu menuliskan rumus jumlah Riemann, tetapi tidak tuntas dalam menulis, artinya PMR lupa rumusnya karena belum paham.

Pada indikator membuat induksi dan menilai induksi, baik pada tes 1 maupun tes 2, PMR masih kurang mampu menarik simpulan sesuai fakta pada keseluruhan soal yang diberikan. Pada soal tes 1 dan 2, PMR tidak mampu menjelaskan langkah-langkah yang digunakan untuk menyelesaikan masalah yang diketahui dengan pertama-tama menggambar masing-masing selang sesuai kategori dan menentukan titik sampel pada masing-masing selang. Dalam proses awal penentuan pembagian selang dan titik sampel masing-masing selang, PMR sudah mengalami kesulitan dan akhirnya mendapatkan hasil yang salah. Ketika diinterview, ternyata belum paham.

Pada indikator mendefinisikan dan menilai definisi, PMR juga belum mampu bertindak dengan memberikan penjelesan lanjut baik pada tes 1 maupun pada tes 2 . Pada soal tes 1 dan 2, PMR belum mampu menjelaskan proses perhitungan yang dilakukan untuk mencari jumlah Riemann. Karena msih bingung dalam menentukan nilai titik sampel maupun $\Delta x$. Sehingga masih kesulitan dalam menentukan nilai $f(x)$ pada masing-masing selang, dan $\Delta x$ pada masing-masing selang. Jadi proses perhitungan selanjutnya menghasilkan hasil yang kurang tepat.

Pada indikator memadukan, PMR pada kedua tes baik tes 1 maupun tes 2 masih kurang mampu dalam memadukan kecenderungan dan dalam membuat keputusan. PMR belum mampu menjelaskan mulai dari apa yang diketahui dalam soal, selanjutnya apa yang ditanyakan, bagaimana cara menyelesaikannya, rumus apa yang digunakan di peroleh dari mana, selanjutnya bagaimana proses perhitungannya sampai diperoleh hasil yang benar. Hal ini dikarenakan, PMR masih belum paham mengenai proses penentuan titik sampel pada soal nonrutin yang berada pada daerah yang berbeda dengan soal rutin yang biasa mereka dapatkan di kelas. Sehingga masih kesulitan dan belum benar dalam penentuan titik sampel yang berakibat pada hasil akhir yang kurang tepat juga. 
Berdasarkan uraian tersebut dapat disimpulkan bahwa hasil penelitian ini sesuai dengan penelitian Nio (2017) yang menyatakan bahwa kemampuan calon guru (mahasiswa) yang tergolong tidak kritis hanya berada pada kategori mampu merumuskan pertanyaan dan melakukan observasi.

\section{SIMPULAN}

Berdasarkan hasil penelitian dan pembahasan dapat disimpulkan bahwa profil kemampuan berpikir kritis mahasiswa berkemampuan pemecahan masalah matematis level rendah menurut kriteria yang dikemukakan oleh Redhana (2013) adalah sebagai berikut. Kemampuan berpikir kritis mahasiswa berkemampuan pemecahan masalah matematis level rendah meliputi mampu merumuskan masalah tetapi masih kurang lengkap dan belum menentukan fakta yang ada pada permasalahan dengan lengkap dan benar, kurang mampu menggunakan bukti yang benar, kurang mampu menarik kesimpulan sesuai fakta, belum mampu bertindak dengan memberikan penjelasan lanjut, dan belum mampu memadukan kecenderungan dan kemampuan dalam membuat keputusan.

\section{DAFTAR PUSTAKA}

Aizikovitsh-Udi, E. (2012). Developing Critical Thinking through Probability Models, Intuitive Judgments and Decision-Making under Uncertainty. Published Doctoral Dissertation, Saarbrucken: LAP Lambert Academic Publishing, ISBN 978-3-83837240-2.

Aizikovitsh-Udi, E. \& Cheng D, (2015). Developing Critical Thinking Skills from Disposition to Abilities: Mathematics Education from Early Chilhood to High School. Scientific Research Publishing: Creative Education, 6, 455-462. Diakses dari http://www.scrip.org/journal/ce.

Chukwuyenum, A.N. (2013). Impact of Critical thinking on Performance in Mathematics among Senior Secondary School Students in Lagos State. Journal of Research \& Method in Education, 3(5), 18-25

Ennis, R. H. (2011). The Nature of Critical Thinking: Sn Outline of Critical Thinking Dispositions and Abilities. Online. Tersedia di http://faculty.education.illinois.edu/rhennis/documents/TheNaturofCriticalThinking_51 711_000.pdf. Diakses 9-03-2016

Facione, P.A. and Facione, N.C. (1994). Holistic Critical Thinking Scoring Rubric. Millbrae, CA: The California Academic Press

Jacob, S.M. (2012). Mathematical achievement and critical thinking skills in asynchronous discussion forums. Procedia - Social and Behavioral Sciences, 31 (2012), 800 - 804

Kalelioglu, F \& Gilbahar, Y. (2013). The Effect of Instructional Techniques on Critical Thinking and Critical Thinking Disposition in Online Discussion. Education Technology \& Society, 17(1): 248-258. Diakses dari http://www.ifets.info/journals/17_1/21.pdf 
Kriel, C. (2013). Creating a Disposition for Critical Thinking in The Mathematics Classroom. Proseding of the $2^{\text {nd }}$ Biennial Conference of the South African Society for Enginering Education, Cape Town, 11-12 June 2013. Diakses dari http://www.sasee.org.za/cms/wpcontent/uploads/2014/06/8.-Creating-a-disposition-forcritical-thinkingin-the-mathematics-classroom.pdf.

Mansoor, F \&Pezeshki, M. (2012). Manipulating Critical Thinking Skills In Test Taking. International Journal of Education, 4, (1), 153-160

Moleong, J. L. (2010). Metodologi Penelitian Kualitatif Edisi Revisi. Bandung: PT Remaja Rosdakarya

Nio, T.H. dkk. (2017). Study on Critical Thinking Skills Basic Prospective Students Primary School Teacher. International Journal of Contemporary Applied Sciences. Vol. 4, No. 1. ISSN: 2308-1365

Osarenren, N. \& Asiedu, A.S. (2007). Counselling Implications on The Role of The New Mathematics Teacher in The Teaching and Learning Mathematics. International (1)

Peter, E E. (2012). Critical Thinking: Essence for Teachiing Mathematics and Mathematics Problem Solving Skill. African Journal of Mathematics and Computer Science Research, 5(3): 39-43. doi: 10.5897/AJMCSR11.161

Redhana, I.W. (2013). Model Pembelajaran Berbasis Masalah untuk Peningkatan Keterampilan Pemecahan Masalah dan Berpikir Kritis. Jurnal Pendidikan dan Pengajaran. Jilid 46 No. 1, Hal 76-86 